Anuja Madan

English Department, Kansas State University, Manhattan, Kansas.

121A, English Building, Kansas State University

Manhattan, KS 66506-6501

Email: amadan@ksu.edu

Anuja Madan is Assistant Professor at the Department of English, Kansas State University, where she teaches courses in World Literature, Global Comics, Children's Literature and Cultural Studies. She received her PhD in English from University of Florida and her M.Phil. and M.A in English from Delhi University. Her co-authored book, Notes of Running Feet: English in Primary Textbooks (with Prof. Rimli Bhattacharya, Sreyoshi Sarkar and Nivedita Basu) grew out of a group study on Indian English-language textbooks. She has published articles on Jean-Luc Godard and picture-book retellings of The Mahabharata. Her two most recent articles on an Indian graphic novel retelling of The Ramayana and mythological Indian animation films have been published in Michelle A. Abate and Gwen A. Tarbox's anthology, Graphic Novels for Children and Young Adults: A Collection of Critical Essays (2017), and The Routledge Companion to International Children's Literature (2017), edited by John Stephens. 


\section{Slow Violence and Water Racism in Sarnath Banerjee's All Quiet in Vikaspuri}

Abstract: This paper claims that Sarnath Banerjee destabilizes the narrative of national economic progress in his graphic narrative All Quiet in Vikaspuri by highlighting ecological crises and destruction of communities. The graphic narrative makes visible the slow violence of ecological destruction and mass displacement (Nixon 2011) triggered by neoliberalism.

Furthermore, it exposes the root causes of the water crisis in Delhi to be the resource imperialism of the elite and middle classes and the privatization of a public good. It shows that the sharp inequality in access to water in Delhi entails a denial of hydraulic citizenship (Anand 2017) to refugees and the poor. The only solution to this crisis, the text suggests, is water democracy and resistance against neoliberal monopolies. The working-class hero's alliance with erstwhile water criminals - one which transcends ethnicity and class - is illustrative of how social justice may be achieved. However, I argue that the underrepresentation of women in the graphic narrative is a significant limitation of the text, especially since it inadvertently perpetuates the invisibility of women perpetuated in development models (Shiva 2010).

Keywords: Indian graphic narratives; neoliberalism; water crisis; ecological destruction; slow violence; citizenship.

Word Count: 8931 words 
Graphic narratives have become a prominent part of Indian English literature over the last decade. Many scholars have discussed the constitutive role of visual practices in bringing the nation into being in the colonial and postcolonial periods (Brosius 2004, Dwyer and Pinney 2001, Freitag 2001, Jain 2007, Pinney 2004, Ramaswamy 2003). The visual is imbricated in India's experience of modernity in central ways. It is no coincidence then, that Indian graphic novelists use a cultural form imported from the west to articulate their own vision of Indian modernity, one which interrogates dominant ideas of the nation in the contemporary moment.

Sarnath Banerjee is a pioneering, critically acclaimed graphic novelist who has gained a cult following after the publication of Corridor (2004). He grew up in Calcutta and Delhi but has been based in Berlin since 2011 (Asokan 2016). Trained in visual communications at Goldsmiths College, Banerjee worked as a documentary filmmaker but became dissatisfied with the medium because he was interested in tonal details of the everyday whereas broadcasting executives would want him to make films on 'big' subjects (Asokan 2016). Banerjee taught himself drawing, with the encouragement of Orijit Sen, after being fascinated by the graphic narrative as a medium which would allow him to "create the full texture of a city, an encyclopaedia of characters" (Asokan 2016).

All Quiet in Vikaspuri, Banerjee's fourth graphic novel, published in 2015 by Harper Collins India, imagines a dystopic future/present in which water scarcity in Delhi leads to bloody water wars.i India has been designated as a water-stressed nation and faces severe water scarcity (Yadav 2017), so the text is as much a commentary on the present as it is a prognosis of the future. It combines different narrative forms and tropes: fable, fantasy, epics, visual essays and burlesque. The comic is hard to categorize into one genre: it may be read as a dystopic narrative, a Homeric tale (as the 
blurb describes it) or as a documentary graphic novel (Adams 2008) but it is more accurately described as a mix of these genres. Like Banerjee's previous works, this comic makes several references to Indian popular culture, local events and Delhi neighborhoods (such as Vikaspuri), so international readers may find some allusions hard to decipher. The commitment to being local is deliberate. In an interview, Banerjee has said that he asked himself: "Do I want to become a bridge maker, do I want my culture to be understood by the west? I have no intentions of doing such things. I'm fine being a little strange to a non-western audience" (Asokan 2016). ii

This paper argues that Banerjee destabilizes the narrative of national economic progress by demonstrating the price paid by marginalized communities for development projects, and by showcasing India's deep class inequalities. The author makes visible the "disposable casualties" (Nixon 2011, 13) of slow violence triggered by neoliberalism. Furthermore, All Quiet in Vikaspuri critiques middle class myopia and exposes its resource imperialism. It shows that the deeply inequitable distribution of water in Delhi entails a denial of hydraulic citizenship (Anand 2017) to refugees and the poor. The comic also exposes casteist and religious discrimination in the nation. The comic subversively has a working-class protagonist who becomes an agent of change against the forces of neoliberalism and corruption. At the end of the text, Banerjee imagines an ideal vision of water democracy forged by an alliance of people from different classes and ethnicities. However, I propose that the underrepresentation of women in the graphic narrative inadvertently perpetuates the invisibility of women perpetuated in development models (Shiva 2010) and is a significant limitation. In the following section, I trace the history of the Indian graphic novel, and situate Banerjee's work within that context. I then proceed to the analysis of the text. 


\section{The Indian Graphic Novel}

There has been much debate on the genesis, history and usage of the term 'graphic novel.' Charles Hatfield (2005) expresses the widely-observed belief that the graphic novel "has become comics' passport to recognition as a form of literature" (ix). Derek Parker Royal (2011) asks, "Does this name [graphic novel] provide more gravitas to the medium, or is it merely a critical (and commercial) affectation? Is 'novel' a useful term to apply to long-form comic or does the imposition of terminology from textual fiction delegitimize the unique project of comics as a medium?" (162). Prominent comics scholars like Hillary Chute and Charles Hatfield propose the use of the broader term 'graphic narrative' instead of 'graphic novel.' Chute (2008) argues that since many of the works grouped under this umbrella are not novels at all, but rich works of nonfiction, the term 'graphic novel' is often a misnomer (453).

In India, the label "graphic novel" was adopted to emphasize "a focus on an auteur model of creativity" that resists the "industrial model's general abuse of creators" (Stoll 2013, 378). Sarnath Banerjee's Corridor (2004) was the first long-form comic marketed as a graphic novel— in fact, Orijit Sen's River of Stories (1994) was the first Indian graphic narrative to be published, but it wasn't marketed as such. Jeremy Stoll (2014) observes that "the development of the shelf for long-form comics in Indian bookstores was the result of [Banerjee's] hard work in publicizing, justifying and making room for the comic as a graphic novel in India's bookselling and publishing culture" (20). While acknowledging the context within which the term Indian graphic novel originated, I follow Hillary Chute and use the terms graphic narrative or comics to de-emphasize the medium's association with textual fiction, especially since many Indian graphic narratives are non-fictional. 
In their style, content and narrative goals, artist-created Indian graphic narratives are very distinct from the mass-produced Amar Chitra Katha comics or Indrajal, Diamond and Raj comics, which were synonymous with children's comics for decades, in much the same way that alternative comics in the US (which spawned the graphic novel) grew in opposition to formula-driven mainstream short-form comics (Hatfield 2005, x). Pepe Galvez argues that the emergence of the graphic novel is representative of a distinctive shift in narrative complexity — in the will to take on deeper and more complex narrative goals (as quoted in Garcia 2015, 22). This shift applies to the emergence of the artist-created Indian graphic novel as well. Indian graphic narratives have been called the cultural and literary 'product' of our times (Varughese and Dudra 2016, 2) and have gained legitimization (Sinha 2016, 162). However, the Indian graphic narrative is an elite medium because of its expensive pricing, and doesn't yet have a wide audience base (Nayar 2016), calling into question the idea that it is the literary product of our age.

Pramod K. Nayar (2016) argues that the Indian graphic narrative as "a new representational mode that re-invigorates the canon" of Indian Writing in English because of its multivalent representational strategies and its insistence on tackling cultural critique of the nation's flaws (7-8). Emma Dawson-Varughese (2018) similarly observes that Indian graphic narratives revolve around "a visuality of the inauspicious," such as social ills, religious intolerance, caste etc., to "disturb ideas of Indianness in the post-millennial moment" (10). Sarnath Banerjee's work is a major intervention in optimistic discourses of a nation aspiring to be a global superpower. His critique focuses on a few major themes: urbanization and urban segregation, the Indian middle class, conservatism, and social inequity. Ragini Tharoor Srinivasan (2016) notes that "whether Banerjee is observing the transformation of Delhi's historic Hauz Khas 
village...into a wealthy residential area or the "global Brooklynification" felt from Bombay to Berlin, he's always telling the story of his country's abortive coming of age.” Ratik Asokan (2016) writes that, "he delves into the psyche of middle-class India - that fraught zone of consumerist aspiration, post-colonial angst, and conservative leaning - and emerges with reports on its citizens' yearnings and fears." Banerjee's erudite cosmopolitanism informs all of his works, as does his sense of humor. He has a sharp sense of the absurd and the ironic, and uses satire with precision to deflate middle class readers' assumptions about themselves and the nation.

\section{Neoliberalism and Slow Violence}

In his book, Slow Violence and the Environmentalism of the Poor, Rob Nixon (2011) defines slow violence as "a violence that occurs gradually and out of sight, a violence of delayed destruction that is dispersed across time and space, an attritional violence that is typically not viewed as violence at all" (2). Examples include "climate change, the thawing cryosphere, toxic drift, biomagnification, deforestation, the radioactive aftermaths of wars, acidifying oceans, and a host of other slowly unfolding environmental catastrophes" (2). Nixon (2011) notes:

structural violence embodied by a neoliberal order of austerity measures, structural adjustment, rampant deregulation, corporate megamergers, and a widening gulf between rich and poor is often a form of covert violence in its own right. (10-13)

All Quiet in Vikaspuri represents a slowly unfolding environmental catastrophe caused by the privatization of Bharat Copper Limited, a fictionalized version of the government-owned firm Hindustan Copper Limited.iii The case study is meant to be representative of the impact of India's turn towards neoliberalism since the economic reforms of the 1990s. 
In a series of clean cut grey-scale realistic panels, we are introduced to the "practically pastoral" life in Tambapur (Tambu means copper in Hindi), an industrial town (Banerjee 2015, 4). We learn that "there was job security [and] the environment was clean" (4). The state-owned company took care of its employees: medical care and education were provided, as were sanitation and maintenance facilities; there were opportunities for sports and general entertainment. One day, we are told, "the company was hit by fluctuations in global copper prices...Back in Delhi, the newly appointed minister of disinvestment was waiting for just such an opportunity" (7). The sketch of the minister bears a close resemblance to Arun Shourie, who was appointed the Minister of Disinvestment by the Bhartiya Janata Party government in 2001 (Vikraman 2017), and who became famous for his policy of accelerated strategic sale of Public Sector Undertakings (or PSUs). Banerjee captures Shourie's agenda in a panel with a single word accompanied by a close-up of the minister: "PRIVATISE (7)." An Australian firm "with a disastrous record in business ethics" (8) leases Bharat Copper and the word "profit" echoes "through Tambapur for the next two years" (9).

In Tambapur, the structural violence triggered by neoliberalism takes the form of environmental degradation and "the disintegration of the township" begins (10). Industrial accidents become common, the hospital becomes unsanitary and unusable, and the water becomes toxic, "leading to terrible diseases" (Banerjee 2015, 11). The inhabitants of the township are affected by the kind of displacement which Nixon (2011) refers to as "the loss of the land and resources beneath [people], a loss that leaves communities stranded in a place stripped of the very characteristics that made it inhabitable" (19). Accompanying visuals of an infected water filtration plant, slimy ponds, an overcrowded hospital, and a closed school are in stark contrast to the wellordered, pleasant life of Tambapur residents depicted earlier. 
The comic showcases the expendability of working class people under a neoliberal regime. When workers rise in protest, they are fired. Nixon (2011) observes that "casualties of slow violence-human and environmental-are the casualties most likely not to be seen, not to be counted. Casualties of slow violence become lightweight, disposable casualties" (13).iv The comic visually highlights this through a panel in which the CEO is drawn in a larger-than-life manner and the workers look very small in comparison, their bodies merged into a huddle and their faces indistinguishable. Whereas at the beginning of this section, the town's inhabitants filled the panels, towards the end, the CEO and security guards occupy most of the frames and the township's inhabitants fall off the pages. The last panel of this section depicts Girish, "a highly trained industrial plumber" who has been fired, as he walks away "into an uncertain future" looking microscopic in the backdrop of a sparse wilderness (Banerjee 2015,12 ), highlighting the invisibility of the victims of slow violence. The "death of a skilled worker, the death of a township, the death of a community" (12) makes huge profits for the corporation involved.v

\section{The Indian Middle Class, Water Racism and Hydraulic Citizenship}

While the section discussed above showcases ecological destruction caused by privatization, other sections of the comic show how privatization is deeply embedded in the Indian middle class psyche despite its negative impact on common people. Delhi's elite and middle classes, who have the resources to pay for privatized water, are represented as being complicit in the inequitable access to water in the city. In the first panels of the graphic narrative, we see a range of people "from all walks of life" (Banerjee 2015, 1) waiting in line at the Regional Passport Office. There is "a general cross-class bonhomie in the air" (2) which is interrupted by a well-off middle-class man who insists that the passport office should privatize, since he doesn't want to wait. 
Banerjee wryly comments: "A percentage of the Indian middle class thinks that corporates are benevolent philanthropic organisations who, in their hearts, desire the betterment of their fellow humans" (3).

In an interview, Banerjee has reflected on the entitlement of the "new middle class," which has been the biggest beneficiary of neoliberalism (Fernandes 2006, xxixxii). He acknowledges that:

the Vikaspuri book grows out of my obsession with our country's obsession with development...I find it very difficult to relate to India's new middle class. This [is] a very patriotic and neoliberal group that mixes religion and economics together. I find them very irksome... They are privileged, but they don't want to talk about their privilege...I tried with this book to mock the South Delhi people (Asokan 2016).

In one of the documentary-style sectionsvi of the book, Prof. P. Satyavadivii (a clear reference to P. Sainath, famous Indian environmental and social activist) wryly comments on the entitlement and ignorance of affluent people living in gated communities in Delhi and Gurgaon (now Gurugram): "If you ask them wherefrom they get their electricity, they will say 'the building provides it.' If you ask them wherefrom they get their water, they will say 'the building provides it.' They speak of their buildings as if they are self-contained ecosystems in the Amazon" (Banerjee 2015, 49). Banerjee names this kind of myopia exhibited by the middle classes and the government “short-termism” (See Varughese 2018, 55-61).

However, Banerjee does more than mock the privilege of urban elite and middle classes: he implicates them in Delhi's water crisis. Girish, the plumber who had been fired from Bharat Copper, is represented as the moral center of the text, and unwittingly uncovers the root causes behind the water crisis. Girish is hired by a Delhi entrepreneur 
named Rastogi to drill into the earth's core in the hope of discovering "the mother of all rivers, the mythical Saraswati" to alleviate water scarcity (Banerjee 2015, 17). In his journey under the surface of the earth, Girish meets a range of people who have been banished below earth to Pataalpuri (Pataal is a Sanskrit word denoting the subterranean realm) for the crime of wasting water.

Jagat Ram is an employee of the Delhi Jal Board (jal means "water" in Hindi) who has been making deals with owners of private tanker companies to divert water from the main supply lines, such that only 37 percent of the water pumped into Delhi reaches the consumer (Banerjee 2015, 22-26). Tanker Rajan, the owner of a private tanker company, steals water from the government and sells it at high prices to five-star hotels and luxury apartments, which run entirely on tankers (25). He makes deals with the police so that he can continue his illegal business without interference. Other water criminals include Mrs. Carrey Jones, the wife of a foreign ambassador, who has her swimming pool drained every time her child urinates in it; Colonel Gambhir, a highranking army officer obsessed with stealing his neighbor's water in the dead of the night; and Aswathy, a senior Municipal Corporation official who has trees cut down and designs water-intensive ornamental gardens with fountains— “the sort South Delhi's affluent class adores but barely visits" (34). Rob Nixon (2011) argues that "the environmentalism of the poor is frequently catalyzed by resource imperialism inflicted on the global South to maintain the unsustainable consumer appetites of rich-country citizens and, increasingly, of the urban middle classes in the global South itself" (22). The people sent down to Pataalpuri for their crimes exemplify this resource imperialism, enabled by a nexus between government officials and private players.

In showcasing affluent Delhiites, corrupt government officials and an opportunistic businessman as water criminals, the comic subverts the discourse around 
criminality and water employed by state agencies. Y. Truelove (2011) notes that "residents living in unauthorized colonies (where private land has been exchanged without government sanction) and slum settlements have no legal access to the piped water supply" (147). Hence, Delhi's poor, marginalized residents are forced to resort to illegal means to procure water. Another study observes: "Hidden and unofficial pathways to accessing water are deployed by the migrants, the poor, the so-called squatters and 'invisible' citizens. These range from stealing water from official pipelines to digging one's own borewell....it is also not uncommon for [them] to resort to informal and 'illegal' means to gain more water (i.e. bribes and drawing political contacts)" (Mehta et al. 2013, 163). The state responds through a targeted criminalization of the poor that is "increasingly backed by the threat of state violence" (Truelove 2011, 150). All Quiet in Vikaspuri overturns the association of water theft with the poor by showing how water is being hoarded by affluent people and businesses.viii

\section{In Hydraulic City: Water and the Infrastructures of Mumbai, Nikhil Anand} (2017) argues that water distribution is deeply tied to citizenship: "the city and its citizens are made and unmade by the everyday practices around water provisioning--practices that are as much about slaking thirst as they are about making durable forms of belonging in the city" (vii). Anand shows that in Mumbai, the state doesn't provide water as a right to the citizens of India, but rather only to those who have established state-sanctioned urban citizenship (57). Much like Delhi, Mumbai's water infrastructure is characterized by inequality: "Mumbai's field engineers design the city's network to deliver only 90 liters per capita to those living in settlements, and nearly twice that quantity to those living in high-rises" (43). Thus, "even as water is drawn from beyond the city's borders, it is mobilized to deny hydraulic citizenship to urban populations 
deemed to be "from outside" (58). Anand argues that migrant bodies are marked as “dangerous outsiders, who, by drawing on the city's resources, are seen as a threat to urban life" (56). Similarly, Mehta et al. (2013) note that in Delhi, "most of the treated water is supplied to the largely elite and middle-class housing colonies leaving poor residents in the villages and informal colonies completely ignored and bypassed" (164). The study suggests that the Indian government's elite biases exclude the rights of the poor to have access to safe water, making their experience of citizenship highly unequal (159-163).

The graphic narrative insightfully ties up the issue of water inequality to citizenship and the othering of refugees. Prof. Satyavadi mentions that the "amount of water delivered per person per day in Delhi Cantonment is 569 litres, in Lutyens Delhi it's 462 litres, and in Mehrauli it's 29 litres" (Banerjee 2015, 115). Needless to say, the first two are posh areas inhabited by affluent Delhiites, and the last is a relatively poor neighborhood. The antagonist of the graphic narrative, a business man named Rastogi, grew up in a refugee colony in south-west Delhi "where there was a chronic shortage of water and electricity" (115). In a biting critique of the structural inequality that characterizes "the environmentalism of the poor" (Nixon 2011) in India, Banerjee writes that "Rastogi grew up on the wrong side of this water racism" (115). Rastogi is humiliated by his peers for wearing dirty clothes and for his unclean appearance (they call him "kachra," meaning "rubbish,"). Banerjee's use of the term "water racism" hints at the xenophobic underpinnings of unequal water distribution in Delhi. Through the plot line about Rastogi, Banerjee shines a spotlight on the denial of hydraulic citizenship to the poor and refugees.

The text highlights another aspect of disproportionate access to water: privatization. Towards the end of the text, it is revealed that "The Great Water War of 
Delhi" is instigated by Rastogi: he directs his team to create rumors and conflicts over water among neighborhoods. Though he initially starts the scheme as a way of taking revenge against the city that had humiliated him, he soon realizes its business potential. As Delhiites start fleeing the city because of the water wars, Rastogi buys large properties in distress sales and sells them overpriced houses in Delhi's satellite city of Gurgaon. We also learn about Rastogi's plan to privatize water. This fictional plot point corresponds to reality: since 1990, the Indian government has encouraged private companies to intervene in the water sector (Purohit 2016). Sampath et al. (2003) observe that "the global market for water in India as a commodity is $\$ 500$ billion globally and $\$ 2$ billion in India... with such huge profits at stake, corporations around the world are striving to ensure that water as a commodity remains in private control."

The comic astutely comments on the way that water is connected to social power in the city. We learn that Rastogi's "aim is to control the distribution of water in the city and thereby rule it" (Banerjee 2015, 130). The comic pushes back against the international discourses on water which are converging to support privatization (Truelove 2011, 144). As Vandana Shiva (2010) argues, "the water crisis is an ecological crisis with commercial causes but no market solutions. Market solutions destroy the earth and aggravate inequality" (15). Banerjee makes a similar claim by showing that water privatization entails monopoly and inequality.

Banerjee's advocacy for equal right to water in this comic can be read as a continuation of his previous works which, according to Dominic Davies $(2018,419)$, "appear to make a claim on the right to the city" and which contest what Surajit Chakravarty and Rohit Negi call neo-liberal urbanism's "spatial apartheid" (quoted in Davies 2018, 419). According to Dominic Davies (2018), Corridor implies "that the experience of reading comics can itself transgress Delhi's infrastructural segregations 
and increasingly privatized spaces" (419). Corridor and Barn Owl have flâneur-like protagonists but "can be seen in fact to satirize an elite flâneurism, mobilizing instead a politically subversive and more socially inclusive "right to the city narrative" (420). Cecile Sandten (2011) claims that in Banerjee's first two graphic novels, Corridor and Barn Owl's Wondrous Capers, "the postcolonial cityscape and its flâneur-like characters are marked by a persistent search for belonging by way of a "postcolonial quest", internal migration and displacement" (512). Like its predecessors, All Quiet in Vikaspuri is marked by the protagonist Girish's search for belonging too after he becomes a migrant, but this search places into sharp relief the environmentalism of the poor, which is characterized by forced displacements and rootlessness.

The allegorical journey of Girish "the psychic plumber" into the subterranean plays on the metaphor of digging deep, as he uncovers a network of characters and factors responsible for the city's structural inequality and water crisis. For Rob Nixon (2011), "contests over what counts as violence are intimately entangled with conflicts over who bears the social authority of witness, which entails much more than simply seeing or not seeing" (16). All Quiet in Vikaspuri makes a subversive move in making a working-class man bear the authority of witnessing what has stayed undercover and unexposed. Moreover, references to Girish as "the psychic plumber" even though playful, suggest that he sees what others can't. Girish's fabular journey contains allusions to Homer and Virgil but most explicitly to Bunyan, since it is called "the plumber's pilgrimage.” As we shall see later, Girish's "great voyage” takes on the undertones of a moral victory. By the end of the text, Girish bear the authority of more than just a witness - he becomes an agent of change and victory against the forces of neoliberalism and corruption.

\section{Imagining and Visibilizing Silenced Communities}


Rob Nixon (2011) discusses "communities whose vigorously unimagined condition becomes indispensable to maintaining a highly selective discourse of national development...narratives of national development are partial narratives...that hide from view communities that inconvenience or disturb the implied trajectory of unitary national ascent" (150). Banerjee makes visible those communities which have been left behind in the discourse of "New India" ix and in doing so, effectively explodes the myth of national economic progress.

In one documentary style section of the text, Professor Satyavadi discusses with Varun Bhalla (the financier behind Tambapur's ruin) a project which Bhalla's company had funded. The proposed steel factory would have choked the fragile river, caused widespread coastal erosion and destroyed the habitat of several endangered species (Banerjee 2015, 76). When the villagers protested their land being taken, they were beaten by the state police and then arrested (77). Banerjee shows that the narrative of national development is built upon the destruction of the environment and state violence against the marginalized. Another hydel (megadam) project in Uttarakhand led to mass displacement and unemployment, and the company doesn't rehabilitate the unemployment. The accompanying images capture the destruction of the environment and the community. For instance, one image shows a horde of people huddled together upon a small tract of land surrounded by flood waters, as they await resettlement. In a powerful image, Varun Bhalla has a nightmare about all meeting all the men who have lost lands and livelihoods because of his company. The image shows a line of men, each mentioning the place he originally belongs to (and has been displaced from). The image is drawn in such a way that the men at the back merge into the gutter, giving the visual impression of the line being never-ending (67). In representing communities that pay the price for India's obsession with development, Banerjee focuses on their 
voicelessness. In the panel discussed above, the men only speak a word each, and in other images, they don't speak at all—an indication of how they have been silenced by the nation-state.

However, the visual and textual absence of women here is felt sharply, as in other places in the comic. The graphic narrative is monopolized by men, and erases the predicament of marginalized women, who are often doubly victimized on account of their gender. Problematically, the only female character in the comic who gets more than a passing mention, Mrs. Carrey Jones (the wife of an ambassador), is a sexualized figure - she is skimpily clad in a bikini whenever she appears and is the object of different men's fantasies. The lack of women is a recurring feature in all of Banerjee's comics. In an interview, Banerjee was asked about why women were "woefully underrepresented" in his work. He replied: "It's a serious handicap...But I haven't figured out an intelligent way to get more female characters into my stories, although I seem to hang out with them, and am mostly influenced by them. It's a weakness, and I have to work on it" (Asokan 2016). Banerjee's acknowledgement of the problem comes across as genuine but especially considering that hydraulic citizenship (and the denial of it) is one of the main concerns of All Quiet in Vikaspuri, I would argue that failing to imagine the condition of marginalized women is a significant limitation of the text.

Struggles over water affect women more severely than men since "everyday water practices are carried out by girls and women, and this group also faces a unique set of obstacles with regard to sanitation" (Truelove 2011, 144). For women of the Global South, "water scarcity means traveling longer distances in search of water" (Shiva 2010, 15). Furthermore, for Vandana Shiva (2010), "the violence to nature, which seems intrinsic to the dominant development model (as we saw above), is also associated with violence to women who depend on nature for drawing sustenance for 
themselves, their families, their societies" (xiv). Shiva claims that women's work in producing sustenance is made invisible in the profit-driven development paradigm, since production for sustenance is seen as non-production (42). The near-absence of women in the comic inadvertently reinforces the invisibility of women that the development agenda has perpetuated.

The underrepresentation of women by an artist who writes narratives advocating for the right to the city and water is especially troublesome because women in India do not have right to public spaces in the same way that men do.x Sanjukta Basu's five-part photo series for FirstPost, "Where are the Women? An Examination of Gender and Public Space in India" (focused on metropolitan cities), shows that Indian men claim different kinds of public spaces with ease, while women are much more constrained in their inhabitation of these spaces and hence are less visible than men because of the regard for their safety and inaccessibility. The absence of women from the public domain in the graphic narrative inadvertently replicates Indian men's dominance over the city and underlines the secondary status of women in a deeply patriarchal society.

However, Banerjee does include the variables of caste and religion in his representation of communities which have been sidelined in India's preoccupation with development. When Varun Bhalla defends his company's decision to invest in the dam project with the much-used rationale of the trickle-down effect, Prof. Satyavadi responds: “My friend, incomes haven't risen in years. 88 per cent Dalits, 88 per cent Adivasis, and 85 per cent Muslims earn below 20 rupees a day" (Banerjee 2015, 81). Satyavadi's comment not only dismantles the commonly held theory of the trickledown effect, it also the shows the uneven impact of neoliberal reforms.xi An Oxfam study notes that "in terms of income, the four poverty groups: the extremely poor, poor, marginal, and vulnerable cover about 88 per cent of the Dalits/ Adivasis, 84.5 per cent 
of Muslims, and 80 percent of the OBCs (Other Backward Castes)...In the higher income categories, Dalits/Adivasis, Muslims and OBCs constitute only 1 per cent, 2.2 per cent, and 2.4 per cent respectively" (Harris-White and Prakash, 2010).xii The text highlights these religious and casteist biases through hard-hitting statistics that many of its upper and middle class readers may not be aware of.

The text also illustrates the plight of the tribal communities (or adivasis) whose way of life is disrupted by development projects. When discussing the impact of development projects, Satyavadi mentions that "dozens of communities [were] resettled; some of them were endangered tribes. Resettling is a polite term for breaking centuries-old ways of living (Banerjee 2015, 80). Arundhati Roy (1999) points out that in the context of dams that the majority of those displaced/ousted have been tribals and Dalit people, which is especially disturbing since they form a minority of India's population. According to Rob Nixon (2011), Adivasis or tribals "have been treated as expendable because they are widely viewed as culturally contemptible and marginal to the core Hindu nationalist parameters of Indian civilization, although the Adivasis' presence in India long predates Hinduism's advent" (163). Although Banerjee doesn't delve into the construction of India as a neoliberal, Hindu nation, he shows that the gains of liberalization are passing by Indians who are already marginalized.

Further, Banerjee warns his privileged readers that this state of affairs is unsustainable. Prof. Satyavadi asks Varun Bhalla: "How long can a society bear such inequality? It is a surprise that people have not exploded yet, but when that happens..." (Banerjee 2015, 84). The image shows a working-class man holding a sword in one hand and the head of a corporate honcho in the other (as indicated by his tie). The next visual shows an empty bowl, while the text reads: “Twitter doesn't bring a revolution, hunger does" (84). The panel seems to satirize the current prime minister Narendra 
Modi's use of Twitter to mobilize supporters and popularize his policies. The author seems to suggest that a violent uprising by the masses would be an inevitable consequence of deep social injustice.

Fittingly then, when Girish emerges from Pataalpuri after having discovered the Saraswati river, he finds out that the water wars of Delhi have started: armed citizens from different Delhi neighborhoods have organized themselves and are fighting over water. All Quiet in Vikaspuri's representation of the conflicts over water, like other aspects of the text, has real life parallels. An April 2018 headline of the Delhi section of an Indian news outlet reads: "Fight over Water Tanker claims second life in city" (Adak 2018). In this incident, acute water crisis led to neighbors in a North Delhi neighborhood getting into a fight, leaving a father and son dead. In September 2016, water riots in Bangalore left one person dead and several injured (Parmar 2016). Significantly, the water wars in the comic are fought along ethnic lines, hinting at the pressures of ecological inequity on India's tenuously woven multi-ethnic fabric.

\section{Hindu Nationalism and Neoliberalism}

I would now like to comment on another important dimension of the text's critique of the nation: the ideology of Hindu nationalism which has become ascendant in the nation since the late 1980s (Basu, Datta, Sarkar et al. 1993, Jaffrelot 1998, Van der Veer 1994). Banerjee's most direct critique of Hindu nationalism is through Rastogi's quest to find the mythical river Saraswati, believed by many Hindus to have been one of the great rivers of the world 4000 years ago (Anand 2016). This expedition has real-life parallels to a slew of costly and unproductive initiatives taken by India's Hindu nationalist government to re-discover the "lost" river Saraswati, mentioned in ancient Hindu scripture Rig Veda (Anand 2016). The search for Saraswati is part of a larger phenomenon of the Hindu Right's use of ancient scriptures and texts to consolidate 
Hindu nationalism (Nanda 2003). Banerjee uses Rastogi's search for the mythical Saraswati to critique the Hindu Right's insistence on making the holy river come to life, and more broadly, its ideology that Hindu culture is the bedrock of the Indian nationstate.

There are other allusions to the machinery of the Hindu Right. Rastogi organizes a group of men to forcibly capture the water source and names it "Rastogi's Saraswati Sena" ("sena," a Hindi word, translates to "army"), which is a clever allusion to Rashtriya Swayamsevak Sangh, also called Rashtriya Seva Sangh (Hindi: National Volunteer Organization). RSS is a prominent Hindu Right organization which conscripts young men into the agenda of disseminating and enforcing Hindutva, "a neologism connoting Hindu-ness but more broadly, the notion that a monolithic and homogenous "Hindu culture" represents the defining feature of the Indian nation" (Lutgendorf 2007, 374). The organization emphasizes paramilitary training and physical strength among its volunteers.

Like RSS youth, who have often instigated violence and rioting, Rastogi's Saraswati Sena attacks Girish and his group in order to take control of the Saraswati river. Towards the end of the graphic novel, a Delhi radio host helping Girish describes the origins of the Saraswati Sena, in what is quite evidently a comment on the ways in which RSS uses young men for their own agenda:

$\mathrm{R}$ has put together a gang of disaffected youth and instilled a sense of entitlement in them. He has made them feel they deserve much more than what they have. And if the democratic institutions are not going to meet their demands, they will snatch what they want from them (Banerjee 2015, 129). The author represents this dynamic between Rastogi and his army visually as well (Figure 1). Rastogi and his right-hand man tower over the "army." The men are 
sketched as a disembodied, homogenous mass, reinforcing the impression of their herdlike mentality. The image illustrates the stripping of men's individualism in the service of an ideology they have been indoctrinated into, and may be read as an illustration of how the RSS operates. The interplay of light and shadow in this panel is symbolic of the men being kept in the dark about their leader's real motivations. As we have seen earlier, Rastogi aims to use Saraswati, the sacred river, for his scheme of privatizing water and gaining control over Delhi. However, nowhere in the text is there an indication that his "army" knows about his real, mercantile motivations.

All Quiet in Vikaspuri hints at the nexus between Hindu nationalism, neoliberalism and the middle class. Arvind Rajagopal (2001) argues that neoliberal reforms were crucial for Hindu nationalist mobilization in India during the late 1980s and early 1990s: "Hindu nationalism represented an attempt to fashion a Hindu public within the nexus of market reforms and the expansion of communications, rather than religious reaction as such" (1). Shankar Gopalakrishnan (2006) discusses an opportunistic alliance between neoliberalism and Hindutva, evident in the fact that Bhartiya Janata Party, the Hindu Right Wing party currently in power, draws its support largely from Hindu elite and middle class voters and regional propertied classes (2807).

In the comic, we meet Hindu characters like Tanker Rajan who have benefited from a neoliberal government. As Tanker Rajan tells Girish how he came to be pulled into Pataalpuri, the image shows Rajan light incense and bow his head in a worshipping pose. He says: "Then came the serious accusation that I was siphoning water from the main [government supply] lines to fill my tankers. I am a trustworthy businessman and a responsible provider. My clients were a demanding lot and I endeavored to fulfil their demands" (Banerjee 2015, 25). There are multiple levels of irony in this panel. Image and text work together to suggest that Rajan applies himself to profiteering with a 
religious zeal. There is a collapse between Rajan's deification of money and his religiosity, implying the mixing of neoliberalism and Hinduism. Rajan is not the only water criminal represented as a Hindu devotee. Aswathy, the corrupt Municipal Corporation official who sold water to private companies, finds himself in Pataalpuri with basic food supplies and a copy of the Manusmriti, a canonical Hindu text which is deeply conservative.

\section{Redemption and Resistance}

The comic's incorporation of narratives tropes from the fable and the epic quest entails a neat resolution and moral victory. Rastogi's plan to monopolize Saraswati river is met with resistance from an unlikely source: the water criminals from Pataalpuri organize themselves and defeat the Saraswati Sena. The route that Girish has drilled underground is used by the Pataalpuri residents to surprise the Saraswati Sena. Colonel Gambhir, the leader of operations, names this route "the plumber's pilgrimage" (Figure 2). This image is repeated in different iterations at the end of the text (Figure 3), and is key to Banerjee's philosophy about how social justice may be achieved. It suggests, not branching out, but anastomosis - the coming together of or connection between what normally diverges. Girish the psychic plumber's "pilgrimage" unites people from diverse backgrounds for the common aim of resistance against a monopoly enabled by a neoliberal system. Girish leads this unlikely band of warriors to a moral victory. Ethnic and class differences can be transcended, the narrative suggests, if there is a commitment to ecological democracy.

The ending of the text articulates a vision of water democracy, even though it relies upon established institutions for its execution. Rastogi gets arrested and sent to jail, and the Delhi Water Board institutes a new program for equitable distribution of water. The newly reformed Delhi Jal Board employee who had found himself in 
Pataalpuri for selling water illegally to private tankers, is made the chairman of this program. Aswathy, the other (erstwhile) corrupt government official, takes up a crusade against timber mafia in Burma. For the water criminals, the journey to the center of the earth has been redemptive and transformative at the same time. Their time in the subterranean seems to have doubled up as punishment and as a catalyst for growth. The water criminals' moral transformation is in keeping with the allegorical and fabular tone of this section of the book.

But what lies behind Banerjee's decision to include the unethical water criminals within the resistance? After all, the text represented the middle classes as characterized by arrogance and privilege. I would argue that by showing the water criminals become part of the solution, Banerjee suggests to his middle and upper class readers that they need to take responsibility for their own complicity in the creation of the water crisis and take steps to rectify their actions. Banerjee's vision for progress includes empathy towards wrongdoers if they are committed to change, and is premised on collective public resistance to corporations and governments. The text advocates for some fundamental principles of water democracy which grassroots organizations have been fighting for, such as the right to clean water being protected for all citizens, and the principle that water cannot be owned as private property and sold for commercial profit (Shiva 2002, 34). Through the use of satire, hard-hitting statistics, powerful visuals and direct critique, Banerjee exhorts his readers to interrogate their own entitlement and myopia, and take concrete action before water wars become an everyday reality.

Acknowledgements: I would like to thank Naomi Wood and Dean Hall for their insightful suggestions at an early stage of drafting this paper. I also thank Kavita Daiya 
and the anonymous reviewers for their valuable feedback on an earlier draft of this paper.

Notes

i The title of the graphic narrative is a riff on Erich Maria Remarque's 1929 novel, All Quiet on the Western Front (and its film adaptation), about German soldiers' experiences of the first world war.

ii Corey Creekmur $(2015,349)$ observes that the most prominent Indian graphic novels...are emphatically "local" or "national" in their content and concerns, frequently taking on notably controversial or culturally specific subjects that may have little interest or familiarity with international audiences...[This] explains why no individual work has enjoyed international "crossover" success."

iii Hindustan Copper Limited was listed for privatization along with other PSUs in 2003. The government finally went ahead with a partial sale in 2017 ("Govt Sells 6.83\% stake in Hindustan Copper, garners Rs. 400 crore").

iv Several scholars have described casualties of neoliberalism in a similar manner. According to David Harvey, "under neoliberalization, the figure of the "disposable worker" emerges As prototypical on the world stage" (169).

$\checkmark$ Interestingly, Banerjee's critique of privatization seems to be one factor which led the original prospective publisher of the book to back off after reading the manuscript. Banerjee has mentioned in an interview that they called him a "communist" (Asokan 2016).

vi Banerjee's experience as a documentary filmmaker evidently informs the tone of some sections of the comic.

vii Satyavadi means "truthful" in Hindi.

viii Vandana Shiva provides some statistics on water exploitation in her 2002 book, Water Wars: "in 1951, the average water availability in India was 3,450 cubic meters per person per year. By 
the late 1990s, it had fallen to 1,250 cubic meters. By 2050 , it is projected to fall to 760 cubic meters. Since 1970, the global per capita water supply has declined by 33 percent. The decline does not result from population growth alone; it is exacerbated by excessive water use as well. During the last century, the rate of water withdrawal has exceeded that of population growth by a factor of two and one-half." (1).

ix It is worth noting here that the current Prime Minister Narendra Modi has fashioned himself as the builder of a "New India" (Talukdar 2017).

x Kaveri Gopalakrishnan beautifully illustrates Indian women's various negotiations in public spaces in a series of comic sketches titled "Basic Space" in Zubaan Books' comics anthology Drawing the Line: Indian Women Fight Back (2015), edited by Larissa Bertonasco, Ludmilla Bartscht and Priya Kurian.

xi Sudipta Bhattacharya $(2013,2)$ argues that the growth process in India following neoliberal reforms has been "uneven and vulnerable to crisis." He notes that contrary to claims that rural and urban poverty has declined, there has been a "steep rise in poverty during the reform period" (3). In a separate study, Vamsi Vakulabharanam and Sripad Motiram (2016) argue that "the distance between classes is increasing, and the elite in particular are pulling away from the rest" (258).

xii Another study observes that regardless of the sector, forward castes and other minority religions have higher salaries than OBCs, Dalits, Adivasis, and Muslims (Desai, Dubey, Joshi 2010).

\section{References}


Adak, Baishali. 2018. "Fight over Water Tanker Claims Second Life in City." India Today, April 13. https://www.indiatoday.in/msn-mail-today/story/fight-overwater-tanker-claims-second-life-in-city-1211125-2018-04-13.

Adams, Jeff. 2008. Documentary Graphic Novels and Social Realism. Pieterlen: Peter Lang.

Anand, Kunal. 2016. "Saraswati River Was Lost 4,000 Years Ago But Now Haryana Govt. Is Reviving It. 100 Cusecs a Time!” IndiaTimes, August 7. https://www.indiatimes.com/news/india/saraswati-river-was-lost-over-4-000years-ago-but-now-haryana-government-is-reviving-it-100-cusecs-at-a-time259568.html

Anand, Nikhil. 2017. Hydraulic City: Water and the Infrastructures of Citizenship in Mumbai. Durham, NC: Duke University Press.

Asokan, Ratik. 2016. "Sarnath Banerjee: The Full Texture of a City." Guernica, April 1. https://www.guernicamag.com/the-full-texture-of-a-city/

Banerjee, Sarnath. 2015. All Quiet in Vikaspuri. Noida: HarperCollins Publishers India.

Bertonasco, Larissa, Ludmilla Bartscht and Priya Kurian, eds. 2015. Drawing the Line:

Indian Women Fight Back. Delhi: Zubaan Books.

Basu, Sanjukta. "Where are the Women? An Examination of Gender and Public Space in India." FirstPost, February 2017.

Basu, Tapan, Pradip Datta, Sumit Sarkar, Tanika Sarkar and Sambuddha Sen. 1993. Khaki Shorts and Saffron Flags: a Critique of the Hindu Right. Tracts for the Times 1. Hyderabad: Orient Longman.

Bhattacharya, Sudipta. 2013. "Introduction: A Critical Look at Two Decades of Market Reform in India." In Two Decades of Market Reforms: Some Dissenting Views, edited by Bhattacharya, 1-26. India and Asia in the Global Economy Series. London: Anthem Press.

Brosius, Christiane. 2004. Empowering Visions: the Politics of Representation in Hindu Nationalism. Anthem South Asian Studies. London: Anthem Press.

Chute, Hillary. 2008. "Comics as Literature? Reading Graphic Narrative.” PMLA 123(2): 453-465.

Creekmur, Corey. 2015. "The Indian Graphic Novel." In A History of the Indian Novel in English, edited by Ulka Anjaria, 348-358. New York: Cambridge University Press.

Davies, Dominic. 2018. "Urban comix: Subcultures, Infrastructures and "The Right to the City" in Delhi." Journal of Postcolonial Writing 54 (3): 411-430. doi: 10.1080/17449855.2018.1461986 
Desai, Sonalde B., Amaresh Dubey, Brij Lal Doshi, Mitali Sen, Abusaleh Shariff and Reeve Vanemman. 2010. Human Development in India: Challenges for a Society in Transition. New York: Oxford University Press.

Dwyer, Rachel and Christopher Pinney eds. 2001. Pleasure and the Nation: the History, Politics and Consumption of Public Culture in India. SOAS Studies on South Asia. New Delhi: Oxford University Press.

Fernandes, Leela. 2006. India's New Middle Class: Democratic Politics in an Era of Economic Reform. Minneapolis: University of Minnesota Press.

Freitag, B. Sandria. 2001. "Visions of the Nation: Theorizing the Nexus between Creation, Consumption and Participation in the Public Sphere." In Pleasure and the Nation: the History, Politics and Consumption of Public Culture in India, edited by Rachel Dwyer and Christopher Pinney, 35-75. SOAS Studies on South Asia. New Delhi: Oxford University Press.

Garcia, Santiago. 2015. On the Graphic Novel. Trans. Bruce Campbell. Jackson: University Press of Mississippi.

Gopalakrishnan, Shankar. 2006. 'Defining, Constructing and Policing a 'New India:' Relationship between Neoliberalism and Hindutva." Economic and Political Weekly 41(26): 2803-2813.

“Govt Sells 6.83\% stake in Hindustan Copper, garners Rs. 400 crore.” 2017. LiveMint, August 3.

https://www.livemint.com/Money/eUlCJwnZefGnjgVQd0zVOM/Govt-sells683-stake-in-Hindustan-Copper-garners-Rs400-cr.html

Harris-White, Barbara and Aseem Prakash. 2010. Social Citizenship in India: a Case for Economic Citizenship. Oxfam India Working Paper Series. Oxfam India. https://www.oxfamindia.org/sites/default/files/VIII.\%20Social\%20Discriminatio n\%20in\%20India-\%20A\%20Case\%20for\%20Economic\%20Citizenship.pdf

Harvey, David. 2005. A Brief History of Neoliberalism. New York: Oxford University Press.

Hatfield, Charles. 2005. Alternative Comics: an Emerging Literature. Jackson, MS: University Press of Mississippi.

Jaffrelot, Christophe. 1998. The Hindu Nationalist Movement and Contemporary Politics. New Delhi: Penguin India.

Jain, Kajri. 2007. Gods in the Bazaar: the Economies of Indian Calendar Art. Durham, NC: Duke University Press.

Lutgendorf, Philip. 2007. Hanuman's Tale: the Messages of a Divine Monkey. New York: Oxford University Press. 
Mehta, Lyla, Jeremy Allouche, Alan Nicol, and Anna Walnycki. 2014. Geoforum 54: 158-166. doi:10.1016/j.geoforum.2013.05.014

Nanda, Meera. 2003. Prophets Facing Backward: Postmodern Critiques of Science and Hindu Nationalism in India. New Jersey: Rutgers University Press.

Nayar, Pramod. 2016. The Indian Graphic Novel: Nation, History and Critique. New York: Routledge.

Nixon, Rob. 2011. Slow Violence and the Environmentalism of the Poor. Cambridge, MA: Harvard University Press.

Parmar, Tekendra. 2016. "A Dispute Over Water Between Two States Has Left One of Them in Flames." Time, September 13. http://time.com/4488895/water-disputeindia-bengaluru-tamil-nadu/

Pinney, Christopher. 2004. Photos of the Gods: the Printed Image and the Political Struggle in India. London: Reaktion Books.

Purohit, Makarand. 2016. "Privatising India's Water is a Bad Idea." The Wire. October 17. https://thewire.in/politics/water-privatisation

Rajagopal, Arvind. 2001. Politics after Television: Hindu Nationalism and the Reshaping of the Public in India. Cambridge: Cambridge University Press.

Ramaswamy, Sumathi. 2003. Introduction. Beyond Appearances? Visual Practices and Ideologies in Modern India. Contributions to Indian Sociology, edited by Ramaswamy, xiii-xxix. New Delhi: Sage Publications.

Roy, Arundhati. 1999. "For the Greater Common Good.” Outlook, 24 May. https://www.outlookindia.com/magazine/story/the-greater-common$\operatorname{good} / 207509$

Royal, Derek Parker. 2011. "Sequential Sketches of Ethnic Identity: Will Eisner's $A$ Contract with God as Graphic Cycle." College Literature 38.3: 150-67.

Sandten, Cecile. 2011. "Intermedial Fictions of the 'New Metropolis': Calcutta, Delhi and Cairo in the Graphic Novels of Sarnath Banerjee and G. Willow Wilson." Journal of Postcolonial Writing 47 (5): 510-522. doi: 17449855.2011 .614786

Sampath, Anitha, Balakrishnan Kedarnath, Chandrika Ramanujam, Hozefa Haidery, Rajesh Rao, Ravishankar Arunachalam, Sandhya Govindraju, Venila Thirumalavan, Vishv Jeet. 2003. "Water Privatization and Implications in India.” Association for India's Development. Austin: University of Texas.

Shiva, Vandana. 2002. Water Wars. Brooklyn: South End Press.

Shiva, Vandana. 2010. Staying Alive: Women, Ecology and Development. 2 nd ed. Brooklyn: South End Press. 
Sinha, Pooja. 2016. "Vignettes of Change: A Discussion of Two Indian Graphic Novels." In South- Asian Fiction in English: Contemporary Transformations, edited by Alex Tickell, 181-197. London: Palgrave Macmillan.

Srinivasan, Ragini Tharoor. 2016. "A Graphic Novelist Captures the Paradoxes of Living in the "New India."' The New Yorker, August 13, 2016. https://www.newyorker.com/books/page-turner/a-graphic-novelist-captures-theparadoxes-of-living-in-the-new-india

Stoll, Jeremy. 2013. "A Creator's History of the Comics Medium in India." International Journal of Comic Art 15 (1): 363-382.

Stoll, Jeremy. 2014. "Telling Stories and Building Community: Making Comics in India." Marg: A Magazine of the Arts 66(2): 16-25. Edited by Aniruddha Sen Gupta.

Talukdar, Sreemoy. 2017. 'Narendra Modi Seeking a 'New India by 2022' In His Independence Day Speech Shows Prime Minister Is Confident of Re-Election." First Post, August 16. https://www.firstpost.com/politics/narendra-modi-demanding-new-india-by2022-in-independence-day-speech-suggests-pm-is-confident-of-re-election3933853.html

Truelove, Yaffa. 2011. “(Re)-Conceptualizing Water Inequality in Delhi, India Through a Feminist Political Ecology Framework." GeoForum 42:143-152. doi:10.1016/j.geoforum.2011.01.004

Varughese, E. Dawson. 2018. Visuality and Identity in Post-Millennial Indian Graphic Narratives. London: Palgrave Macmillan.

Varughese, E. Dawson and Rajinder Dudrah. 2016. Introduction, South Asian Popular Culture, 14(1-2): 1-5. doi: 10.1080/14746689.2016.1261431

Vakulabharanam, Vamsi and Sripad Motiram. 2016. "Mobility and Inequality in Neoliberal India." Contemporary South Asia 24(3): 257-270. doi:10.1080/09584935.2016.1203862

Van der Veer, Peter. 1994. Religious Nationalism: Hindus and Muslims in India. Berkeley: University of California Press.

Vikraman, Shaji. 2017. "In Fact: The Gradual Evolution of India's Disinvestment Policy." The Indian Express, April 5. http://indianexpress.com/article/explained/in-fact-the-gradual-evolution-ofindias-disinvestment-policy/

Yadav, Yatish. 2017. "PMO Told That Water Wars are Nearing in a Water-Stressed India." The New Indian Express, March 26. http://www.newindianexpress.com/nation/2017/mar/26/pmo-told-that-waterwars-are-nearing-in-water-stressed-india-1585967.html 
Figure 1. Rastogi giving commands to his Saraswati Sena to prepare for fighting. Reproduced with the permission of the author.

Figure 2. Col. Gambhir names the route which Girish has drilled under the earth the "plumber's pilgrimage." Reproduced with the permission of the author.

Figure 3. This image of anastomosis symbolizes the collective action needed to defeat neoliberal monopolies. Reproduced with the permission of the author.

\section{Images:}

\section{Figure 1}

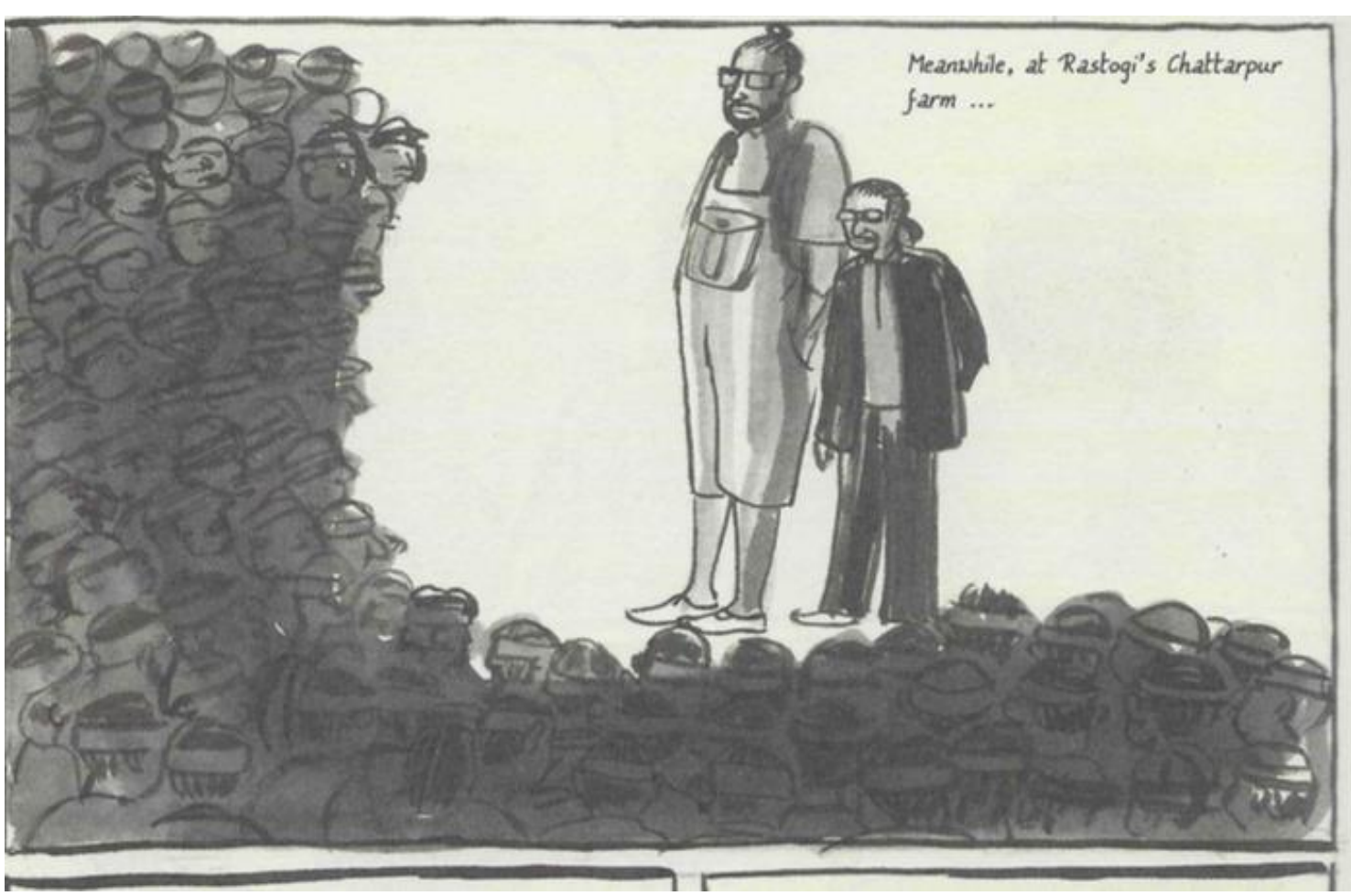


Figure 2

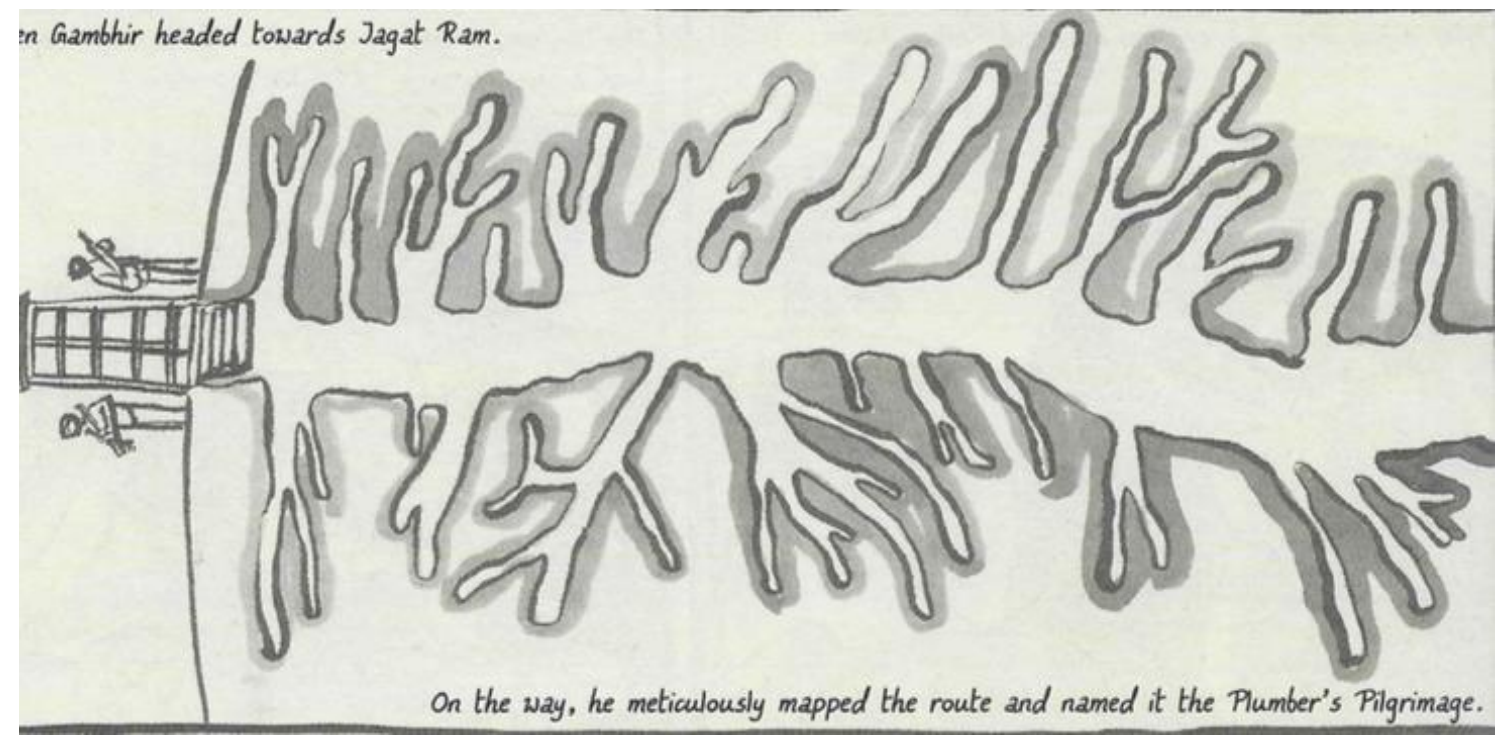


Figure 3

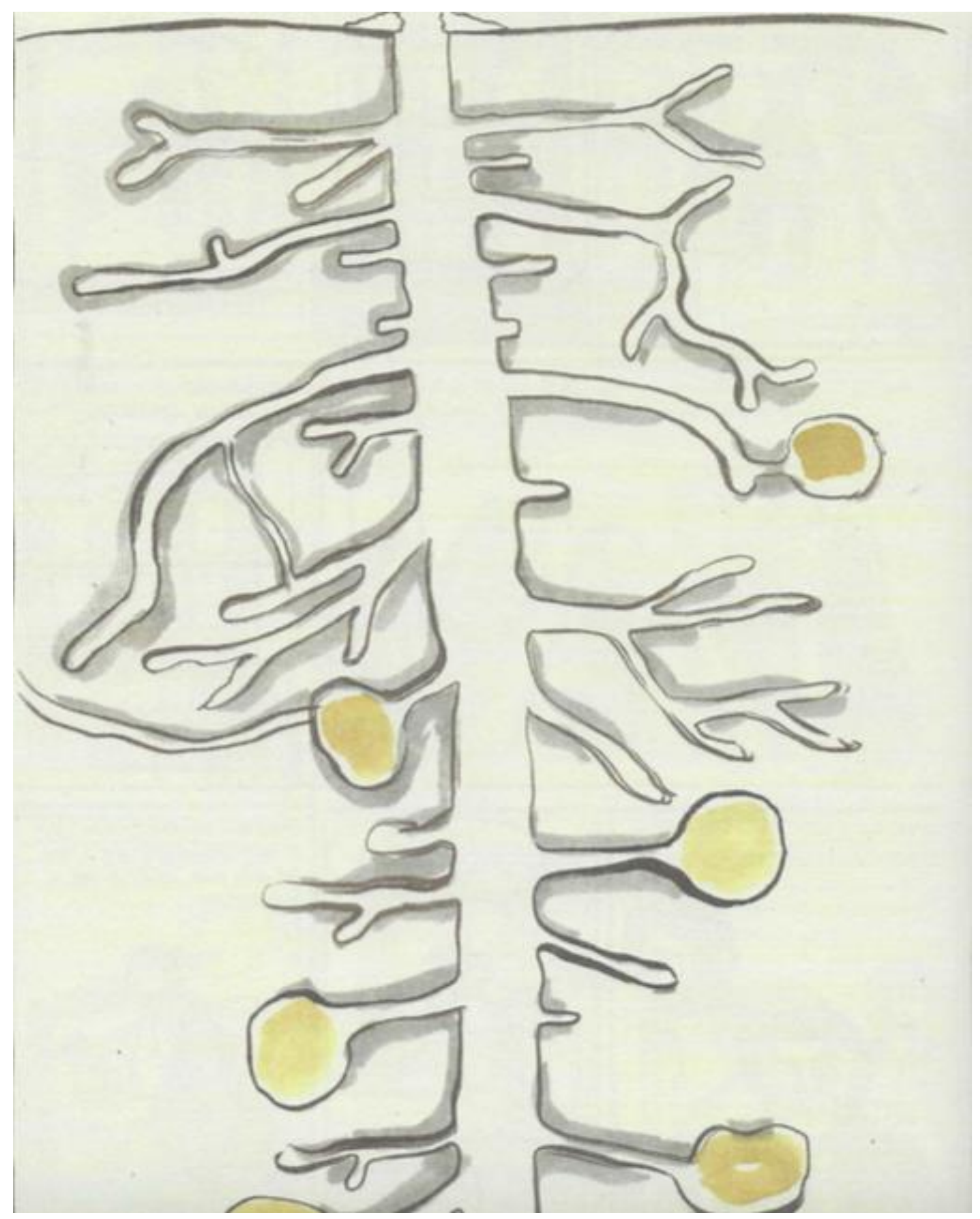

